Moral Foods 


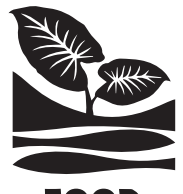

FOOD

IN ASIA

AND THE Series Editors:

PACIFIC Christine R. Yano and Robert Ji-Song Ku 


\section{Moral Foods}

THE CONSTRUCTION OF

NUTRITION AND HEALTH IN

MODERN ASIA

Edited by Angela Ki Che Leung

and Melissa L. Caldwell

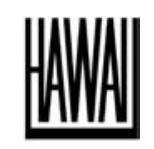

University of Hawai'i Press Honolulu 
(C) 2019 University of Hawai'i Press

All rights reserved

Printed in the United States of America

$\begin{array}{llllllllllll}24 & 23 & 22 & 21 & 20 & 19 & 6 & 5 & 4 & 3 & 2 & 1\end{array}$

\section{Library of Congress Cataloging-in-Publication Data}

Names: Leung, Angela Ki Che, editor. | Caldwell, Melissa L., editor.

Title: Moral foods : the construction of nutrition and health in modern Asia / edited by Angela Ki Che Leung and Melissa L. Caldwell.

Other titles: Construction of nutrition and health in modern Asia | Food in Asia and the Pacific.

Description: Honolulu : University of Hawai'i Press, [2019] | Series: Food in Asia and the Pacific Includes bibliographical references and index. Identifiers: LCCN 2018041490 | ISBN 9780824876708 (cloth ; alk. paper) Subjects: LCSH: Diet-Asia. | Food habits-Asia. | Food consumptionMoral and ethical aspects-Asia.

Classification: LCC GT2853.A78 M67 2019 | DDC 394.1/2095-dc23

LC record available at https://lccn.loc.gov/2018041490

Cover art: (right) Rice with sesame seeds in black bowl. Photo by Vitchakorn Koonyosying on Unsplash. (left) Macro photography of rice with bokeh light background. Photo by rawpixel on Unsplash.

University of Hawai'i Press books are printed on acid-free paper and meet the guidelines for permanence and durability of the Council on Library Resources. 